\title{
Bronchial responsiveness in active steelworkers
}

\author{
J.L. Corhay*, T. Bury*, R. Louis*, J.P. Delavignette*, J.M. Kayembe*, G. Weber**, \\ A. Albert+, M.F. Radermecker*
}

\begin{abstract}
Bronchial responsiveness in active steelworkers. J.L. Corhay, T. Bury, R. Louis, J.P. Delavignette, J.M. Kayembe, G. Weber, A. Albert, M.F. Radermecker. @ERS Journals Ltd 1998. ABSTRACT: Coke-oven workers are exposed to dust and irritant gases. Therefore they are at risk of developing lung diseases including chronic bronchitis. Nonspecific bronchial hyperresponsiveness (BHR) has been advocated as a potential risk factor predisposing to the development of chronic bronchitis. In a previous study, we showed that prevalence of BHR was higher in retired coke-oven workers than in retired blast furnace workers. The present study was carried out to determine the prevalence of BHR in active steelworkers.

Thus, 137 coke-oven workers and 150 blast furnace workers underwent clinical examination, a standardized questionnaire for the study of respiratory symptoms, pulmonary function testing and methacholine aerosol challenge.

The study demonstrates a higher prevalence and degree of BHR (provocative concentration of methacholine causing a $20 \%$ fall in forced expiratory volume in one second $\left(\mathrm{PC}_{20}\right)$ $\left.\varnothing \mathrm{g} \mathrm{mg} \cdot \mathrm{mL}^{-1}\right)$ in coke-oven workers than in blast furnace workers $(31.4$ versus $6.7 \%$; $\mathrm{p}<0.001$ ). Moreover, the frequency of respiratory symptoms and basal bronchial obstruction were greater among coke-oven workers with BHR in nonresponders. The basal maximum expiratory flow from $25-75 \%$ of forced vital capacity and the respiratory symptoms were correlated with bronchial responsiveness. The lack of correlation observed between BHR and the intensity of smoking or years spent in coke-oven environment may be explained by the high proportion of smokers, the worker turnover in the steel plant, and the "healthy worker effect".

In conclusion, the higher prevalence and degree of bronchial hyperresponsiveness in coke-oven workers suggests that coke-oven pollutants are more intense irritants than those that escape from blast furnaces.

Eur Respir J 1998; 11: 272-277.
\end{abstract}

Depts of *Pneumology, **Experimental Nuclear Physics and +Biostatistics, University of Liège, Liège, Belgium

Correspondence: J.L. Corhay

Dept of Pneumology

University of Liège

CHU Sart Tilman B35

B-4000 Liège

Belgium

Fax: 3243668846

Keywords: Bronchial responsiveness methacholine challenge steelworkers

Received: February 121997

Accepted after revision November 171997

This study was supported by a grant from the European Coal and Steel Community (ECSC no. 7280/03/042).
In the steel industry, coke is mainly used as fuel for blast furnaces to retrieve iron from iron ores. Coke is derived from coal by destructive heating in the absence of oxygen.

During the coking process, large quantities of gas, fumes and dusts escape from the coal (coal dusts, coal tar, nitrogen dioxide $\left(\mathrm{NO}_{2}\right)$, sulphur dioxide $\left(\mathrm{SO}_{2}\right)$, benzene, phenols, ammonia, polycyclic aromatic hydrocarbons, carbon monoxide (CO), etc.). Thus, coke-oven workers are exposed to dust and irritant gases, and are therefore at risk of developing a variety of lung diseases including chronic bronchitis [1-3]. Noxious gases, such as $\mathrm{SO}_{2}, \mathrm{NO}_{2}$ and ozone $\left(\mathrm{O}_{3}\right)$, may cause bronchial hyperresponsiveness (BHR) in animals, but also in humans [4-7]. Nonspecific BHR has been advocated as a potential risk factor predisposing some cigarette smokers to the development of chronic obstructive pulmonary disease (COPD). This hypothesis is supported by longitudinal studies in individuals with $[8,9]$ or without [10-12] established COPD among whom increased BHR was associated with accelerated rates of decline in lung function.

Until now, BHR in steelworkers has received little attention in the literature. In a previous study [13], we showed that retired coke-oven workers had a higher preva- lence of BHR $(65 \%)$ than retired blast furnace workers $(17 \%)$. The present $3 \mathrm{yr}$ research project was designed to determine the prevalence of BHR in active coke-oven and blast furnace workers, and to investigate the relationship between bronchial reactivity (BR), smoking habits, years spent at work, baseline lung function, atopy and respiratory symptoms. It is the purpose of this paper to report the results obtained from this $3 \mathrm{yr}$ study.

\section{Subjects and methods}

\section{Subjects and study design}

The study population consisted of 314 randomly selected active production workers from a steel plant in the Liège industrial basin (Cockerill Sambre, Liège, Belgium). Selection of workers was made by computer from a population of approximately 1,500 production employees working with coke-oven or blast furnace. In our study, the matching procedure was not used and population characteristics were displayed as part of the results. These workers were invited by mail to participate in the study. They 
were asked to undergo a clinical examination, a standardized questionnaire for the study of respiratory symptoms [14], pulmonary function tests (flow-volume curve, spirometry and body plethysmography) and a methacholine aerosol challenge with an adapted Cockcroft method [15]. Coke-oven workers were defined as subjects working on or near the ovens (oven regulator, support setter, shield setter, door cleaner, pusher machine operator, coke car drivers, maintenance personnel on the ovens, or switch operator); byproduct workers (tar distillery, benzene plant, sulphate plant, generator gas plant, etc.) were not included in this study. During the coking process, workers are exposed to large quantities of gas, fumes and dusts (coal dusts, coal tar, $\mathrm{NO}_{2}, \mathrm{SO}_{2}$, benzene, phenols, ammonia, polycyclic aromatic hydrocarbons, CO, carbon dioxide, etc.). All blast furnace workers enrolled in the study had been engaged as production workers in the process of iron smelting (casters, checkers of barrows and mechanical filling of blast furnace, furnacemen or unskilled workers). Exposures in the blast furnaces are varied and include heat, noise, chemical agents (e.g. $\mathrm{CO}$ and $\mathrm{SO}_{2}$ ), polycyclic aromatic hydrocarbons, asbestos, silica, iron dusts and fumes, and potential metallic oxides (impurities) that are in iron ores.

The study was approved by the Ethics Committee of the University of Liège.

\section{Questionnaire}

The European Coal and Steel Community (ECSC) standardized questionnaire for the study of respiratory symptoms [14] was administered by the same experienced chest physician to each worker. Workers were classified as symptomatic when giving one or more positive responses to the following questions: 1) cough or phlegm on most days; 2) wheezes apart from colds; 3 ) chest tightness or breathless when walking on level ground; and 4) attacks of asthma. We defined chronic bronchitis as cough and sputum production for at least 3 months $\cdot \mathrm{yr}^{-1}$ for $2 \mathrm{yrs}$ or more. Additional questions dealt with occupational history, diseases treated and smoking habits of the workers. Nonsmokers were defined as lifelong nonsmokers. Current smokers were defined as those smoking one or more cigarettes per day. Past-smokers were those who stopped smoking for at least 1 month prior to the examination. Smoking was measured in pack-years, a pack-year being equal to 25 cigarettes per day for 1 yr (in Belgium one pack contains 25 cigarettes).

Subjects were considered to have a history of allergy if they answered positively to one of the following two questions: "Have you ever had hay fever?" and "Do you get eye, nasal or respiratory symptoms if you are exposed to house dust, domestic animals or fungi?"

Allergic status was confirmed by allergy skin tests.

\section{Allergy skin tests}

Skin-prick tests were performed to extract common allergens, including cat, house dust, Dermatophagoides pteronyssinus and a mixture of five grass pollens (Stallergens ${ }^{\circledR}$, Fresnes, France), and a control saline solution and a histamine solution. Atopy was defined as the presence of a wheal, with a diameter Š50\% of the histamine wheal, in response to at least one allergen.

\section{Pulmonary function tests}

Vital capacity (VC), forced expiratory volume in one second (FEV1), total lung capacity (TLC), functional residual capacity (FRC) and residual volume (RV) were determined using a watersealed spirometer (Pulmonet III; SensorMedics, Bilthoven, The Netherlands). Forced vital capacity (FVC) and maximum expiratory flow from 75$25 \%$ of FVC (MEF25-75) were determined using a pneumotachograph (Flowscreen, Jaeger, Würzburg, Germany). Specific airway conductance ( $\mathrm{s} G$ aw, calculated from the reciprocal of resistance airway and corrected for lung volume) was measured by a variable pressure constant-volume body plethysmograph (Jaeger). Spirometric measurements were performed with the subject seated and wearing a noseclip. Three technically acceptable measurements were made for each subject and converted to body temperature and pressure saturation (BTPS). Results were expressed as percentages of the predicted values [15].

\section{Inhalation challenge}

Subjects were asked not to smoke for $2 \mathrm{~h}$ before the challenge. Methacholine chloride solutions (ICN, AsseErlegen, Belgium) were dissolved in sterile saline solution, stored at $4^{\circ} \mathrm{C}$, and used within 2 weeks of preparation. Bronchial reactivity was measured using the continuous tidal breathing method adapted from the method described by CоскCROFT et al. [16]. An aerosol of methacholine chloride in sterile normal saline was generated by a Hudson's nebulizer (airflow $8 \mathrm{~L} \cdot \mathrm{min}^{-1}$, output $0.3 \mathrm{~mL} \cdot \mathrm{min}^{-1}$ ). The subjects inhaled the aerosol, at quiet tidal breathing, in sitting position for 2 min through a face mask using a noseclip. The subjects first inhaled sterile normal saline to provide a control value and then a methacholine solution in gradually increasing concentrations doubling at $5 \mathrm{~min}$ intervals (from 0.5 to $32 \mathrm{mg} \cdot \mathrm{mL}^{-1}$ ). FEV 1 was measured $90 \mathrm{~s}$ after each inhalation. The test was stopped when the FEV1 had fallen by at least $20 \%$ from the control value or when the methacholine concentration of $32 \mathrm{mg} \cdot \mathrm{mL}^{-1}$ was reached. The concentration was plotted against the FEV1, and the provocative concentration required to produce a fall in FEV1 of $20 \%$ from the postsaline baseline value (PC20), was calculated by linear interpolation (between the last two points) on the dose-response curve. Subjects with PC20 ð32 $\mathrm{mg} \cdot \mathrm{mL}^{-1}$ were classified as responders and those with $\mathrm{PC}_{20}>32 \mathrm{mg} \cdot \mathrm{mL}^{-1}$ as nonresponders. A PC20 threshold value of $8 \mathrm{mg} \cdot \mathrm{mL}^{-1}$ was selected to define BHR. Thus, according to bronchial responsiveness, steel workers were classified into three categories according to PC20: BHR (ð8 $\left.\mathrm{mg} \cdot \mathrm{mL}^{-1}\right)$; minor BHR (8.1-32 $\left.\mathrm{mg} \cdot \mathrm{mL}^{-1}\right)$; and nonresponders $\left(>32 \mathrm{mg} \cdot \mathrm{mL}^{-1}\right)$.

\section{Statistical analysis}

Results were expressed as mean \pm SD for continuous variables and as percentages for categorical data. We app- lied a log-transform to the PC20 values to normalize their dis- 
tribution. Group means were compared by Student's t-test or one-way analysis of variance (ANOVA). Whenever necessary, a Bonferroni correction was applied to account for multiple comparisons. Frequencies were compared by Chi-squared test for contingency tables. Multiple regression analysis was used to assess the effect of risk factors on airway responsiveness to methacholine in coke-oven workers. Regression coefficients were given with their standard errors (SE). The association between occupational exposure and the presence or absence of BR was investigated by logistic regression analysis. This method allows for simultaneous adjustment of covariates, such as age, smoking habits and baseline lung function level (FEV1, MEF25-75). It also yields adjusted odds ratios (ORs) together with their $95 \%$ confidence intervals (CIs). Results were considered to be significant at the $5 \%$ critical level $(\mathrm{p}<0.05)$

\section{Results}

\section{Population characteristics}

Among the 314 workers who were invited to enrol in the study, $287(91.4 \%)$ agreed to participate. There were 137 coke-oven workers and 150 blast furnace workers.

Characteristics of the two groups of workers are given in table 1. There were no significant differences among groups with respect to age, smoking habits, years spent at work and presence of respiratory symptoms. The proportion of current and past smokers was high in both groups, averaging $80 \%$. However, some lung function tests (results being expressed as percentage of predicted values) differed significantly between the two groups of workers.

Although individual results were still within the normal range in both groups, we found that coke-oven workers had significantly lower FEV1 and MEF25-75 mean values by comparison to blast furnace workers. In coke-oven workers $s G$ aw results were slightly lower than reference values. Twenty five steelworkers had chronic bronchitis among whom 12 were blast furnace workers $(8.0 \%)$ and 13 cokeoven workers $(9.5 \%)$. On the basis of patient history, 11 steelworkers were considered as atopic: five were coke

Table 1. - Characteristics of coke-oven and blast furnace workers enrolled in the study

\begin{tabular}{lcc}
\hline Characteristics & $\begin{array}{c}\text { Blast furnace } \\
\text { workers } \\
(\mathrm{n}=150)\end{array}$ & $\begin{array}{c}\text { Coke-oven } \\
\text { workers } \\
(\mathrm{n}=137)\end{array}$ \\
\hline Age yrs & $41 \pm 8$ & $42 \pm 9$ \\
Smokers and exsmokers \% & 78.0 & 81.7 \\
Smoking history pack-years & $13.5 \pm 12.9$ & $15.5 \pm 12.2$ \\
Time spent at work yrs & $15.9 \pm 9.3$ & $14.6 \pm 8.3$ \\
FEV1 \% pred & $100 \pm 12.7$ & $96.8 \pm 13.5 *$ \\
FEV1/VC \% & $80.8 \pm 6.2$ & $80.4 \pm 6.5$ \\
MEF25-75 \% pred & $96.7 \pm 30.4$ & $82.4 \pm 27.0 * * *$ \\
sGaw \% pred & $71.8 \pm 33.0$ & $67.8 \pm 32.0$ \\
Respiratory symptoms \% & 16.7 & 21.2 \\
\hline Results are expressed
\end{tabular}

Results are expressed as mean \pm SD or as percentage. FEV 1 : forced expiratory volume in one second; \% pred: percentage of predicted value; VC: vital capacity; MEF25-75: maximum expiratory flow from $75-25 \%$ of forced vital capacity; $s G$ aw: specific airway conductance. $*, * * *: \mathrm{p}<0.05, \mathrm{p}<0.001$. oven workers (3.6\%) and six blast furnace workers (4.0\%). Allergic status was confirmed in all cases by allergy skin tests (most common allergens).

Methacholine challenge and prevalence of bronchial responsiveness in steelworkers

As seen from table 2, overall positive bronchial responsiveness (PC20 ð32 $\mathrm{mg} \cdot \mathrm{mL}^{-1}$ ) was significantly more frequent in coke-oven workers (48.9\%) than in blast furnace workers $(18.7 \%)$, yielding a prevalence ratio of $2.62(95 \%$ CI: 2.16-3.17). When comparing nonresponders to responders with minor BHR or with BHR, the prevalence ratio was 1.99 (95\% CI: $1.14-3.45)$ and 4.64 (95\% CI: 2.45-8.81), respectively. For responders, the mean PC20 value was significantly $(\mathrm{p}<0.01)$ lower in coke-oven workers $\left(9.8 \pm 7.4 \mathrm{mg} \cdot \mathrm{mL}^{-1}\right)$ than in blast furnace workers $(15.5 \pm$ $\left.10.7 \mathrm{mg} \cdot \mathrm{mL}^{-1}\right)$, thus emphasizing the difference between the two groups of workers.

The relationship between professional exposure (cokeoven or blast furnace) and BR (presence or absence) was also investigated by logistic regression analysis. ORs were adjusted for age, smoking habits and baseline lung function level (FEV1 and MEF25-75). Working in a coke-oven environment was significantly related to bronchial responsiveness $(\mathrm{OR}=3.58 ; 95 \% \mathrm{CI}$ : $1.97-6.50)$, to minor BHR $(\mathrm{OR}=2.34 ; 95 \% \mathrm{CI}: 1.14-4.80)$ and to $\mathrm{BHR}(\mathrm{OR}=7.41$; 95\%CI: 2.99-18.3).

Characteristics of coke-oven workers according to bronchial responsiveness

We classified coke-oven workers into three classes according to their $\mathrm{PC}_{20}$ value, as described in the Subjects and methods section: 43 had BHR, 24 had minor BHR and 70 were nonresponders. As shown in table 3, the subgroups were similar with respect to age, smoking habits and years spent at work. However, the frequency of respiratory symptoms increased with the degree of bronchial responsiveness: 8.6, 20.8 and 41.9\%, respectively. Pulmonary function tests, especially FEV1 and MEF25-75, were significantly lowered in coke-oven workers with BHR or minor BHR by comparison to nonresponders.

Table 2. - Results of the methacholine challenge test applied to 287 steelworkers. Prevalence of bronchial responsiveness in blast furnace and coke-oven workers

\begin{tabular}{lcll}
\hline $\begin{array}{l}\text { PC20 } \\
\text { challenge test }\end{array}$ & $\begin{array}{c}\text { Blast } \\
\text { furnace } \\
\text { workers } \\
(\mathrm{n}=150)\end{array}$ & $\begin{array}{c}\text { Coke-oven } \\
\text { workers } \\
(\mathrm{n}=137)\end{array}$ & $\begin{array}{c}\text { Prevalence } \\
\text { ratio }\end{array}$ \\
\hline Nonresponders & $122(81.3)$ & $70(51.1)$ & \\
Responders & $28(18.7)$ & $67(48.9)^{* * *}$ & $2.62(2.16-3.17)$ \\
$8.1-32 \mathrm{mg} \cdot \mathrm{mL}^{-1}$ & $18(12)$ & $24(17.5)$ & $1.99(1.14-3.45)$ \\
$\partial 8 \mathrm{mg} \cdot \mathrm{mL}^{-1}$ & $10(6.7)$ & $43(31.4)^{* * *}$ & $4.64(2.45-8.81)$ \\
\hline Mean $\pm \mathrm{sD} \mathrm{mg} \cdot \mathrm{mL}^{-1}$ & $15.5 \pm 10.7$ & $9.8 \pm 7.4 * *$ & \\
Range $\mathrm{mg} \cdot \mathrm{mL}^{-1}$ & $0.9-32$ & $1-32$ & \\
\hline
\end{tabular}

Results are expressed as absolute number with percentage in parenthesis, or for prevalence ratio as ratio with $95 \%$ confidence interval in parenthesis. Bronchial responsiveness was defined by a provocative concentration of methacholine causing a $20 \%$ fall in forced expiratory volume in one second (PC20) ð32 $\mathrm{mg} \cdot \mathrm{mL}^{-1} \cdot * *, * * *: \mathrm{p}<0.01, \mathrm{p}<0.001$. 
Table 3. - Demographic data and lung function tests in 150 blast furnace workers and 137 coke-oven workers according to bronchial responsiveness categories

\begin{tabular}{|c|c|c|c|c|c|c|}
\hline & \multicolumn{2}{|c|}{ Nonresponders $\left(\mathrm{PC} 20>32 \mathrm{mg} \cdot \mathrm{mL}^{-1}\right)$} & \multicolumn{2}{|c|}{ Minor BHR (PC20 8.1-32 mg.mL-1) } & \multicolumn{2}{|c|}{$\mathrm{BHR}\left(\mathrm{PC}_{20}\right.$ ð8 mg·mL-1) } \\
\hline & Blast furnace & Coke-oven & Blast furnace & Coke-oven & Blast furnace & Coke-oven \\
\hline Workers $\mathrm{n}$ & 122 & 70 & 18 & 24 & 10 & 43 \\
\hline \multicolumn{7}{|l|}{ Demographic data } \\
\hline Age yrs & $41.3 \pm 7.5$ & $40.9 \pm 9.0$ & $39.4 \pm 9.9$ & $42.2 \pm 8.3$ & $44.3 \pm 8.7$ & $43.3 \pm 8.3$ \\
\hline Smoking pack-years & $12.2 \pm 12.3$ & $15.1 \pm 12.5$ & $17.3 \pm 13.7$ & $15.4 \pm 9.6$ & $22.6 \pm 14.2 *$ & $19.4 \pm 12.0$ \\
\hline Time spent at work yrs & $15.8 \pm 9.1$ & $13.5 \pm 8.9$ & $13.8 \pm 9.6$ & $15.4 \pm 7.7$ & $22.0 \pm 8.8$ & $16.0 \pm 7.6$ \\
\hline Respiratory symptoms \% & 9.0 & 8.6 & $38.9 *$ & 20.8 & $70.0^{*}$ & $41.9 *$ \\
\hline \multicolumn{7}{|l|}{ Lung function data } \\
\hline FEV $1 \%$ pred & $102.0 \pm 12.1$ & $102.0 \pm 10.4$ & $93.5 \pm 10.0 *$ & $94.5 \pm 13.9 *$ & $88.9 \pm 15.6^{*}$ & $89.4 \pm 14.6 *$ \\
\hline $\mathrm{FEV}_{1} / \mathrm{VC}$ & $81.5 \pm 5.7$ & $81.7 \pm 5.5$ & $79.4 \pm 7.5$ & $80.0 \pm 6.5$ & $74.7 \pm 5.3^{*}$ & $77.8 \pm 7.4^{*}$ \\
\hline MEF25-75 \% pred & $101.0 \pm 30.1$ & $95.2 \pm 23.2$ & $87.7 \pm 21.8$ & $80.9 \pm 29.5 *$ & $62.8 \pm 21.8 *$ & $62.3 \pm 17.7 *$ \\
\hline sGaw $\%$ pred & $73.8 \pm 33.7$ & $77.5 \pm 31.5$ & $67.6 \pm 24.3$ & $63.2 \pm 28.4$ & $55.2 \pm 35.5$ & $54.7 \pm 30.1 *$ \\
\hline
\end{tabular}

Results are expressed as mean $\pm \mathrm{SD}$, as percentage or absolute number. $*$ : $\mathrm{p}<0.05$, different from nonresponders (analysis of variance and Bonferroni tests). BHR: bronchial hyperresponsiveness. For further definition, see legends to tables 1 and 2.

Determinants of airways responsiveness to methacholine in coke-oven workers

We also looked for potential determinants of airways responsiveness to methacholine in coke-oven workers. By stepwise multiple regression analysis, we found that only MEF25-75 (regression coefficient: 0.0115 $\pm 0.004 ; \mathrm{p}<0.01$ ) and the presence or absence of respiratory symptoms (regression coefficient: $-0.345 \pm 0.176 ; \mathrm{p}<0.01$ ) were significant predictors of bronchial responsiveness (log of PC20). However, the percentage of variance explained by the two selected variables was small $\left(\mathrm{R}^{2}=0.18\right)$. No significant correlation was found between $\log \mathrm{PC}_{20}$ and age, years spent at work, intensity of smoking, FEV1, FEV1/VC ratio and specific conductance.

Bronchial responsiveness in coke-oven workers with chronic bronchitis

Thirteen coke-oven workers $(9.5 \%)$ were suffering from chronic bronchitis among whom eight (61.5\%) had BHR and two $(15.4 \%)$ had minor BHR. The prevalence of BHR was significantly increased in workers suffering from chronic bronchitis by comparison to other coke-oven workers without chronic bronchitis (61.5 versus $28.2 \%$; $\mathrm{p}<0.05$ ). However, the prevalence of minor BHR was similar in the two groups (15.4 for workers with chronic bronchitis versus $17.7 \%$ for workers without chronic bronchitis). Comparison between atopic and nonatopic coke-oven workers was not possible due to the small number of atopic workers $(3.6 \%)$ in this group.

Characteristics of blast furnace workers according to bronchial responsiveness

Similarly, we classified blast furnace workers into three categories according to their PC20 value: 10 had BHR, 18 had minor BHR and 122 were nonresponders. As shown in table 3, the subgroups were identical with respect to age and years spent at work. Tobacco consumption (in packyears) was significantly greater in workers with BHR as compared with nonresponders.

Pulmonary function tests (FEV1, FEV1/VC, MEF25-75) were significantly decreased in workers with BHR in comparison to nonresponders. The prevalence of respiratory symptoms increased significantly with the level of BR to methacholine: 9.0, 38.9 and $70.0 \%$, respectively.

In each category, we also compared the characteristics of these workers with coke-oven workers (table 3). Except for a higher duration at work for blast furnace workers with BHR, demographic data, respiratory symptoms and lung function tests were similar in each category.

Determinants of airways responsiveness to methacholine in blast furnace workers

We also looked for potential determinants of airways responsiveness to methacholine in blast furnace workers. By stepwise multiple regression analysis, we found that only MEF25-75 (regression coefficient: 0.253 $\pm 0.069 ; \mathrm{p}<$ $0.005)$ was related to bronchial responsiveness $(\log P C 20)$. The percentage of variance explained by this variable was $31 \%$. No significant correlation was found between $\log$ $\mathrm{PC}_{20}$ and age, years spent at work, intensity of smoking (in pack-years), presence of respiratory symptoms, FEV1, $\mathrm{FEV} 1 / \mathrm{VC}$ ratio and specific conductance.

Bronchial responsiveness in blast furnace workers with chronic bronchitis

Twelve blast furnace workers $(8.0 \%)$ were suffering from chronic bronchitis among whom four $(33.3 \%)$ had BHR and four $(33.3 \%)$ had minor BHR. No comparison between atopic and nonatopic blast furnace workers could be performed due to the small proportion of atopic workers $(4.0 \%)$ in this group.

\section{Discussion}

The present study demonstrates a significantly increased prevalence and degree of BHR in active coke-oven workers when compared to active blast furnace workers. Since the primary objective of the study was not concerned with defining the prevalence of BHR in the general population, a control group was not included. Coke-oven workers were therefore compared with blast furnace workers, the latter subjects working in a dusty environment (blast 
furnace), living in the same area and having the same socioeconomic status as coke-oven workers. Moreover, a previous study [13] showed that retired blast furnace workers have BHR in the normal range.

Whereas one third of the coke-oven workers had BHR, there were only $6.7 \%$ with BHR in the blast furnace workers group. In the literature, BHR in the general population is reported to range 10-14\% [17-19].

The high prevalence of BHR in coke-oven workers might be the consequence of airway inflammation secondary to a synergistic mechanism including coke-oven pollutants (a complex mixture with many dusts, fumes and gases) and smoking habits. It is known that minor inflammation occurs more often in smokers exposed to dust and fumes than in nonexposed smokers [20]. On the other hand, a potentiation was demonstrated between smoking habits and dust (amorphous silica) exposure, in inducing a small airway disease, as indicated by the respiratory flow rates [21]. We also found that frequency of respiratory symptoms and basal bronchial obstruction was greater among coke-oven workers (as well as among blast furnace workers) with BHR than in nonresponders. Moreover, the basal MEF25-75 (an indicator of small airway obstruction) and the respiratory symptoms (bronchial inflammation) were correlated with BHR.

There is evidence from many studies that the effects of atopy, airway calibre and smoking can interact with hyperresponsiveness [17, 19, 22, 23]. In our study, the rate of atopy (on the basis of clinical history) among steelworkers was lower than that reported in the general population, so we failed to detect any correlation between atopy and BHR. We would like to underline that preemployment examination had been conducted for workers entering the steelplant. Workers with a history of asthma and other important allergic disorders had been excluded from the work force. It is possible that a limited number of atopic subjects have been engaged in the industry, simply because allergy skin tests are not part of the pre-employment examination: some of these atopic subjects may leave the industry because of the development of symptoms. In this study, we found that prevalence of atopy was significantly lower among steelworkers than in the general population, because of a selection factor. We failed to find any correlation between smoking habits and BHR, although smokers (mainly $>40$ yrs of age) were generally found to be more often hyperresponsive than nonsmokers [11, 19, 22-24]. The lack of correlation between smoking habits and BHR in our study may be explained by the small number of nonsmokers studied.

It is possible that the moderate increases in BHR are reactions to environmental exposure, and thus represent intermediate events in the pathway to COPD [8-12]. Therefore, BHR in coke-oven workers without airflow obstruction might identify those workers at increased risk for COPD as compared to workers without BHR. However, only a prospective longitudinal study (currently under way) on the same population of workers could answer such questions as whether the development of BHR increases the risk of subsequent airway obstruction and then COPD, or whether BHR is only the consequence of abnormal airway geometry. As mentioned above, it is known that there is a strong correlation between measured BHR to methacholine and baseline airway calibre [25].
The "healthy worker effect" has been found in many occupational groups and may attenuate exposure-response relationships observed in workers employed in hazardous industries [26, 27]. Subjects who are less susceptible to effects of certain exposures may remain at work, whereas susceptible subjects tend to change occupations or leave the work force prematurely. This bias is especially strong in cross-sectional studies, such as the present study, when the workforce studied represents a survivor population. Selection out of a workforce because of respiratory complaints, found in several groups working in dusty environments, will tend to weaken any relationship between BHR and occupational exposure (duration at work). CHAU et al. [28] did not find any adverse effect of occupational exposure on ventilatory function in retired coke-oven plant workers from Lorraine. The functional values were however mostly lower than predicted values and the most reduced index was the mean expiratory flow from $25-75 \%$ of FVC. The authors suggested that pulmonary function indices were probably overestimated because of exclusion of deceased subjects, the healthy worker effect and the bias of participants.

Moreover, worker turnover appears to be especially increased in dusty jobs, particularly if the steelplant meets economic difficulties. The high proportion of smokers, the high turnover in the steelplant and the "healthy worker effect" could explain the lack of correlation between BHR and the intensity of smoking or years spent in coke-oven environment.

In conclusion, our study has shown an increased prevalence and degree of bronchial hyperresponsiveness in coke-oven workers compared to blast furnace workers. This could be the consequence of airway inflammation secondary to a synergistic mechanism including many coke-oven pollutants and smoking habits. Bronchial responsiveness was correlated with the respiratory symptoms and basal bronchial obstruction, but not with the intensity of smoking or years spent in coke-oven environment.

\section{References}

1. Walker DD, Archibald M, Attfield D. Bronchitis in men employed in the coke industry. Br J Ind Med 1971; 228: 358-363.

2. Swaen GMH, Slangen JJM, Volovics A, Hayes RB, Scheffers T, Sturmans F. Mortality of coke plant workers in the Netherlands. Br J Ind Med 1991; 48: 130-135.

3. Griffith DE, Levin JL. Occupational bronchitis. In: Bardana EJ, Montanaro A, O'Hollaren MT, eds. Occupational Asthma. Philadelphia, Hanley Belfus Inc., 1992; pp. 63-75.

4. Orehek J, Massari JP, Gayrard P, Grimaud C, Charpin J. Effect of short-term, low-level nitrogen dioxide exposure on bronchial sensitivity of asthmatic subjects. J Clin Invest 1976; 57: 301-307.

5. Frampton MW, Morrow PE, Cox C, Gibb FR, Speers DM, Utell MJ. Effects of nitrogen dioxide exposure on pulmonary function and airway reactivity in normal humans. Am Rev Respir Dis 1991; 143: 522-527.

6. Seltzer J, Bigby BG, Stulborg M. $\mathrm{O}_{3}$ induced change in bronchial reactivity to methacholine and airway inflammation in humans. J Appl Physiol 1986; 60: 1321-1326.

7. Magnussen H. Experimental exposures to nitrogen dioxide. Eur Respir J 1992; 5: 1040-1042. 
8. Barter CE, Campbell AH. Relationship of constitutional factors and cigarette smoking to decrease in 1-second forced expiratory volume. Am Rev Respir Dis 1976; 113: 305-314.

9. Kanner RE. The relationship between airways responsiveness and chronic airflow limitation. Chest 1984; 1: 54-57.

10. Tabona M, Chan-Yeung M, Enarson D, Maclean L, Dorken E, Schulzer M. Host factors affecting longitudinal decline in lung spirometry among grain elevator workers. Chest 1984; 6: 782-786.

11. Taylor RG, Joyce H, Gross E, Holland F, Pride NB. Bronchial reactivity to inhaled histamine and annual rate of decline in FEV1 in male smokers and ex-smokers. Thorax 1985; 40: 9-16.

12. Vollmer WM, Johnson LR, Buist AS. Relationship of response to a bronchodilator and decline in forced expiratory volume in one second in population studies. Am Rev Respir Dis 1985; 132: 1186-1193.

13. Corhay JL, Mariz S, Bury Th, Tulippe Ch, Delavignette JP, Radermecker MF. Bronchial hyperresponsiveness in healthy preretired coke-oven workers. Eur Respir J 1991; 4: 251 .

14. Minette A, Aresini G, Sanna-Randaccio F, Seaton A, Smidt U, Teculescu D. Notes on the ECSC questionnaire for the study of respiratory symptoms. Third Edition, Commission of the European Communities, Luxembourg, 1988.

15. Quanjer PhH. Standardized lung function testing. European Community for Coal and Steel. Bull Eur Physiopathol Respir 1983; 19 (Suppl. 5): 45-51.

16. Cockcroft DW, Killian DN, Mellon JJA, Hargreave FE. Bronchial reactivity to inhaled histamine: a method and clinical survey. Clin Allergy 1977; 7: 2235-2243.

17. Cockcroft DW, Murdock KY, Berscheid BA. Relationship between atopy and bronchial responsiveness in a random population. Ann Allergy 1984; 53: 26-29.

18. Cockcroft DW, Murdock KY, Berscheid BA, Gore BP. Sensitivity and specificity of histamine $\mathrm{PC} 20$ determina- tion in a random selection of young college students. $J$ Allergy Clin Immunol 1992; 89: 23-30.

19. Burney PGJ, Britton JR, Chinn S, et al. Descriptive epidemiology of bronchial reactivity in an adult population: results from a community study. Thorax 1987; 42: 38-44.

20. Kennedy SM, Wright JL, Mullen JB, Paré PD, Hogg JC. Pulmonary function and peripheral airway disease in patients with mineral dust or fume exposure. Am Rev Respir Dis 1985; 132: 1294-1299.

21. Chaudat D, Frisch C, Barrat G, Marsac J, Conso F. Fonction respiratoire et exposition à la silice amorphe. Colloque INSERM 1991; 203: 209-214.

22. Gerrard JW, Cockcroft DW, Minsk JT, Cotton DJ, Poonawala R, Dosman JA. Increased nonspecific reactivity in cigarette smokers with normal lung function. Am Rev Respir Dis 1980; 122: 577-581.

23. O'Connor GT, Sparrow D, Segal MR, Weiss ST. Smoking, atopy and methacholine airway responsiveness among middle-aged and elderly men. Am Rev Respir Dis 1989; 140: 1540-1546.

24. Cerveri I, Bruschi C, Zoiam C, et al. Smoking habit and bronchial reactivity in normal healthy subjects. Am Rev Respir Dis 1989; 140: 191-196.

25. Kennedy SM, Burrows B, Vedal S, Enarsson DA, Chan Yeung M. Methacholine responsiveness among working populations. Relationship to smoking and airway caliber. Am Rev Respir Dis 1990; 142: 1377-1383.

26. Ernst P, Dales RE, Nunes F, Becklake MR. Relation or airway responsiveness to duration of work in a dusty environment. Thorax 1989; 44: 116-120.

27. Koskela RS, Luoma K, Hernberg S. Turnover and health selection among foundry workers. Scand J Work Environ Health 1976; 2 (Suppl.): 90-105.

28. Chau N, Bertrand J-P, Guenzi M, et al. Lung function in retired coke-oven plant workers. Br J Ind Med 1992; 49: 316-325. 